\title{
Phytochemicals and bioactive properties of Ilex paraguariensis: An in-vitro comparative study between the whole plant, leaves and stems
}

Aloisio H.P. Souza ${ }^{1,2,3,4}$, Rúbia C.G. Corrêa ${ }^{1,3,4}$, Lillian Barros ${ }^{1}$, Ricardo C. Calhelha ${ }^{1,5}$, Celestino Santos-Buelga ${ }^{6}$, Rosane M. Peralta ${ }^{3}$, Adelar Bracht ${ }^{3}$, Makoto Matsushita ${ }^{3}$, Isabel C.F.R. Ferreira, ${ }^{1, *}$

${ }^{1}$ Mountain Research Centre (CIMO), ESA, Polytechnic Institute of Bragança, Campus de Santa Apolónia, 1172, 5301-855 Bragança, Portugal.

${ }^{2}$ Federal Institute of South Mato Grosso, Campus Coxim, 79400-000 Coxim, Brazil.

${ }^{3}$ Department of Biochemistry and Department of Chemistry, State University of Maringa, Av. Colombo, 5790, 87020-900 Maringa - PR, Brazil.

${ }^{4}$ CAPES Foundation, Ministry of Education of Brazil, 70.040-020, Brasilia, DF, Brazil.

${ }^{5}$ Centre of Chemistry, University of Minho, Campus de Gualtar 4710-057 Braga, Portugal.

${ }^{6}$ GIP-USAL, Facultad de Farmacia, Universidad de Salamanca, Campus Miguel de Unamuno, 37007 Salamanca, Spain.

* Author to whom correspondence should be addressed (e-mail: iferreira@ipb.pt telephone +351-273-303219; fax +351-273-325405). 


\begin{abstract}
Leaves, stems and whole plant of Ilex paraguariensis (yerba mate) were characterized in terms of their chemical composition and biological activities in order to determine which part of the plant is more interesting to develop bioactive formulations. The yerba mate samples contain at least five free sugars, five organic acids, eighteen fatty acids, one tocopherol, nine hydroxycinnamoyl derivatives and two flavonols. The leaves extract revealed the highest antioxidant activity, correlating with its highest levels of phenolic compounds. By contrast, the stems extract showed the highest antiinflammatory potential and was also the most potent against MCF-7 and HepG2 cell lines, probably due to the presence of other phytochemicals. The absence of hepatotoxicity of the extracts was confirmed in porcine liver primary cells. Although the yerba mate extracts have been widely studied, this report shows for the first time the distinct potentialities of each individual part of the plant.
\end{abstract}

Keywords: yerba mate; phytochemicals; antioxidant activity; anti-inflammatory activity; cytotoxicity 


\section{Introduction}

In the past decades, research has shown the potential exploitation of plant products as a source of new bioactive compounds for the production of nutraceuticals, functional foods, and food additives (Gil-Chávez et al., 2013). Leaves, stems and flowers may present distinct biological activities (Dias et al., 2014). Moreover, the study of plants used as infusions and other beverages has gained crescent significance in the scientific field, due to its proven constituents with bioactive potentials, well-being advantages and functional ingredients (Farzaneh \& Carvalho, 2015).

Ilex paraguariensis A. St. Hilaire, from the family of holy plants, Aquifoliaceae, is a South American tree that can reach $18 \mathrm{~m}$ in height, from which yerba mate is obtained (Márquez, Martínez, Guerra, Fariña, Boido \& Dellacassa et al., 2013). The powder made with yerba mate leaves and fine stems is widely consumed in Argentina, southern of Brazil, Paraguay and Uruguay, both as a source of caffeine in place of tea and coffee, and as a therapeutic agent due to its known pharmacological properties such as antioxidant, anti-inflammatory, antitumor, and weight reducing activities (Bracesco, Sanchez, Contreras, Menini, \& Gugliucci, 2011). It constitutes the basis for the preparation of some very traditional and popular beverages namely "chimarrão" (green dried leaves prepared with hot water), "tererê" (green dried leaves prepared with cold water) and mate tea (roasted leaves prepared with hot water or used to produce soft drinks) (Lima, Oliveira, Silva, Maia, Moura \& Lisboa, 2014).

Thus, the yerba mate production also represents an important economic activity for some South American countries, especially after the herb has gained worldwide recognition and research on its properties has extended to countries such as Korea, Japan, China and USA (Bracesco et al., 2011). Argentina is currently the first exporter 
of yerba mate while Uruguay has the highest per capita consumption of 6-8 kg/person/year (Márquez et al., 2013).

Recent studies, both in-vivo and in-vitro, have evidenced several therapeutic qualities of I. paraguariensis, including hepatoprotective (Tamura et al., 2013), neuroprotective (Branco et al., 2013), hypocholesterolemic (de Morais et al., 2009; Bravo et al., 2014), diuretic and antirheumatic (Isolabella, Cogoi, López, Anesini, Ferraro \& Filip, 2010), anti-obesity (Lima et al., 2014) and antimicrobial (Martin, Porto, Alencar, Glória, Corrêa, \& Cabral, 2013) effects, among others. Furthermore, the antioxidant (de Mejía, Song, Heck, \& Ramirez-Mares, 2010; Peres, Tonin, Tavares \& Rodriguez-Amaya, 2013; Blum-Silva, Chaves, Schenkel, Coelho \& Reginatto, 2015; Boaventura et al., 2015b) and anti-inflammatory (Tsai, Tsai, Wuc, Tseng \& Tsai, 2010; Arçari et al., 2011, Lanzetti et al., 2012) properties of aqueous yerba mate extracts have been extensively investigated. However, studies on the cytotoxic potential of $I$. paraguariensis (de Mejía et al., 2010, Boaventura et al., 2015a) remain scarce. Besides, to the author's knowledge, there are no previous reports differentiating between individual parts of the plant, i.e., leaves and stems.

In the present work, leaves, stems and whole plant of I. paraguariensis (yerba mate) were characterized in terms of their chemical composition and in-vitro biological activities in order to determine which part of the plant presents better potential for developing bioactive formulations. The biological activities include antioxidant, antiinflammatory and cytotoxic potentials of methanol/water extracts, along with an assessment of its toxicity, tested in a primary cell culture of porcine liver cells.

\section{Material and methods}

\subsection{Plant material}


I. paraguariensis A. St. Hil. plant (dry leaves and stems, stored at vacuum) was purchased from a local market in Maringá city, Paraná (Brazil). The plant was collected during the January crop of 2013. This region of production presents subtropical climate, average altitude of $923.5 \mathrm{~m}$ and during 2012 the registered rainfall was of $80-180 \mathrm{~mm}$ (National Institute of Metrology, 2012). Sampling consisted of 3 batches of $1 \mathrm{~kg}$, collected at intervals of 10 days. The parts of the plant were separated through sieves to obtain leaves and stems. Afterwards, all samples (entire plant, leaves and stems) were grounded using an electric grinder and the standardization of granulometry was made by sieves of 20 mesh. The obtained powders were then mixed to guarantee the homogeneity of the samples, which were stored in a desiccator at room temperature (average $25^{\circ} \mathrm{C}$ ), and protected from light, until further analysis.

\subsection{Standards and Reagents}

Acetonitrile (99.9\%), n-hexane (97\%) and ethyl acetate $(99.8 \%)$ were of HPLC grade from Fisher Scientific (Lisbon, Portugal). The fatty acids methyl ester (FAME) reference standard mixture 37 (standard 47885-U) was purchased from Sigma (St. Louis, MO, USA), as also were, L-ascorbic acid, trolox (6-hydroxy-2,5,7,8tetramethylchroman-2-carboxylic acid), sugar standards $(\mathrm{D}(-)$-fructose, $\mathrm{D}(+)$ melezitose, $\quad \mathrm{D}(+)$-sucrose, $\quad \mathrm{D}(+)$-glucose, $\quad \mathrm{D}(+)$-trehalose and $\mathrm{D}(+)$-raffinose pentahydrate), acetic acid, ellipticine, sulphorhodamine B (SRB), trypan blue, trichloroacetic acid (TCA), Tris, and lipopolysaccharide (LPS). Phenolic compound standards were purchased from Extrasynthèse (Genay, France). Racemic tocol (50 $\mathrm{mg} / \mathrm{mL})$ and tocopherols $(\alpha-, \beta-, \gamma-$, and $\delta$-isoforms) were purchased from Matreya (Pleasant Gap, PA, USA). 2,2-Diphenyl-1-picrylhydrazyl (DPPH) was obtained from Alfa Aesar (Ward Hill, MA, USA). Fetal bovine serum (FBS), L-glutamine, Hank's 
balanced salt solution (HBSS), trypsin-EDTA (ethylenediaminetetraacetic acid), penicillin/streptomycin solution (100 U/mL and $100 \mathrm{mg} / \mathrm{mL}$, respectively), RPMI-1640 and DMEM media were from Hyclone (Logan, Utah, USA). The Griess reagent system was purchased from Promega Corporation (Madison, WI, USA). Water was treated in a Milli-Q water purification system (TGI Pure Water Systems, Greenville, SC, USA).

\subsection{Chemical characterization}

\subsubsection{Macronutrients composition and energetic contribution}

The analyses of the nutritional composition (proteins, fat, carbohydrates and ash) were performed through standard procedures $(\mathrm{AOAC}, 2005)$. The crude protein content $(\mathrm{N} \times$ 6.25) of the samples was estimated by the macro-Kjeldahl method; the crude fat was determined by extracting a known weight of a powdered sample with petroleum ether, using a Soxhlet apparatus; the ash content was determined by incineration at $600 \pm 15^{\circ} \mathrm{C}$. Total carbohydrates were calculated by difference. Energy was calculated according to the following equation: Energy $=4 \times(\mathrm{g}$ protein $+\mathrm{g}$ carbohydrate $)+9 \times(\mathrm{g}$ fat $)$, and further converted to $\mathrm{kJ}$.

\subsubsection{Hydrophilic compounds}

Free sugars. Free sugars were determined with a high performance liquid chromatograph (HPLC) apparatus consisting in an integrated system with a pump (Knauer, Smartline system 1000, Berlin, Germany), degasser system (Smart line manager 5000) and an auto-sampler (AS-2057 Jasco, Easton, MD, USA), coupled to a refraction index detector (RI detector Knauer Smartline 2300) as previously described (Barros et al., 2013). Sugars identification was made by comparing the relative retention times of sample peaks with standards $(\mathrm{D}(-)$-fructose, $\mathrm{D}(+)$-melezitose, $\mathrm{D}(+)$-sucrose, 
$\mathrm{D}(+)$-glucose, $\mathrm{D}(+)$-trehalose and $\mathrm{D}(+)$-raffinose pentahydrate). The chromatographic separation was achieved with a Eurospher 100-5 $\mathrm{NH}_{2}$ column $(4.6 \times 250 \mathrm{~mm}, 5 \mu \mathrm{m}$, Knauer) operating at $30{ }^{\circ} \mathrm{C}(7971 \mathrm{R}$ Grace oven). The mobile phase was acetonitrile/deionized water, 70:30 $(v / v)$ at a flow rate of $1 \mathrm{~mL} / \mathrm{min}$. Data were analyzed using Clarity 2.4 Software (DataApex, Podohradska, Czech Republic). Quantification was based on the RI signal response of each standard, using the internal standard (IS, melezitose) method and by using calibration curves obtained with the commercial standards of each compound. The results were expressed as g per $100 \mathrm{~g}$ of dry weight.

Organic acids. Organic acids were determined following a procedure previously described (Barros et al., 2013). The analysis was performed using a Shimadzu 20A series UFLC (Shimadzu Coperation, Kyoto, Japan). Separation was achieved on a SphereClone (Phenomenex, Torrance, CA, USA) reverse phase $\mathrm{C}_{18}$ column (5 $\mu \mathrm{m}, 250$ $\mathrm{mm} \times 4.6 \mathrm{~mm}$ i.d) thermostatted at $35^{\circ} \mathrm{C}$. The elution was performed with $3.6 \mathrm{mM}$ sulphuric acid with a flow rate of $0.8 \mathrm{~mL} / \mathrm{min}$. Detection was carried out in a DAD, using $215 \mathrm{~nm}$ and $245 \mathrm{~nm}$ (for ascorbic acid) as preferred wavelengths. The organic acids found were quantified by comparison of the area of their peaks recorded at 215 or $245 \mathrm{~nm}$ with calibration curves obtained with commercial standards of each compound (ascorbic acid; citric acid; malic acid; oxalic acid; quinic acid). The results were expressed as g per $100 \mathrm{~g}$ of dry weight.

\subsubsection{Lipid composition}

Fatty acids. Fatty acids were determined after a transesterification procedure as described previously (Barros et al., 2013). The fatty acids profile was analyzed with a DANI 1000 gas chromatographer (GC) equipped with a split/splitless injector and a 
flame ionization detector (FID at $260{ }^{\circ} \mathrm{C}$ ). The separation was achieved using Macherey-Nagel (Düren, Germany) column (50\% cyanopropyl-methyl-50\% phenylmethylpolysiloxane, $30 \mathrm{~m} \times 0.32 \mathrm{~mm}$ i.d. $\left.\times 0.25 \mu \mathrm{m} \mathrm{d}_{\mathrm{f}}\right)$. The oven temperature program was as follows: the initial temperature of the column was $50^{\circ} \mathrm{C}$, held for $2 \mathrm{~min}$, then a $30{ }^{\circ} \mathrm{C} / \mathrm{min}$ ramp to $125^{\circ} \mathrm{C}, 5^{\circ} \mathrm{C} / \mathrm{min}$ ramp to $160{ }^{\circ} \mathrm{C}, 20^{\circ} \mathrm{C} / \min$ ramp to $180{ }^{\circ} \mathrm{C}$, $3{ }^{\circ} \mathrm{C} / \mathrm{min}$ ramp to $200{ }^{\circ} \mathrm{C}, 20{ }^{\circ} \mathrm{C} / \mathrm{min}$ ramp to $220^{\circ} \mathrm{C}$ and held for $15 \mathrm{~min}$. The carrier gas (hydrogen) flow-rate was $4.0 \mathrm{~mL} / \mathrm{min}(0.61 \mathrm{bar})$, measured at $50{ }^{\circ} \mathrm{C}$. Split injection (1:40) was carried out at $250^{\circ} \mathrm{C}$. Fatty acid identification was made by comparing the relative retention times of FAME peaks from samples with standards (37 fatty acids methyl ester, standard 47885-U). The results were recorded and processed using Clarity 4.0.1.7 Software (DataApex, Podohradska, Czech Republic) and expressed as relative percentage of each fatty acid.

Nutritional quality index of lipid fraction. Atherogenicity indexes (IA) were determined as follows: $\mathrm{IA}=[(12: 0+(4 \times 14: 0)+16: 0)] /($ MUFA $+n-6+n-3)$, and thrombogenicity index $(\mathrm{IT})=(14: 0+16: 0+18: 0) /[(0.5 \times$ MUFA $)+(0.5 \times n-6)+(3 \times n-3)+(n-3 / n-6)]$ (Ulbricht et al. 1991). Hypocholesterolemic/hypercholesterolemic ratio $(\mathrm{h} / \mathrm{H})=(18: 1 \mathrm{n}-9$ $+18: 2 n-6+20: 4 n-6+18: 3 n-3+20: 5 n-3+22: 5 n-3+22: 6 n-3) /(14: 0+16: 0)$ (SantosSilva, Bessa \& Santos-Silva, 2002).

Tocopherols. Tocopherols were determined following a procedure previously described (Barros et al., 2013). Analysis was performed by HPLC (equipment described above), and a fluorescence detector (FP-2020; Jasco) programmed for excitation at $290 \mathrm{~nm}$ and emission at $330 \mathrm{~nm}$. The chromatographic separation was achieved with a Polyamide II (5 $\mu \mathrm{m}, 250 \mathrm{~mm} \times 4.6 \mathrm{~mm}$ i.d.) normal-phase column from YMC Waters (Waters, Lisbon, Portugal) operating at $30^{\circ} \mathrm{C}$. The mobile phase used was a mixture of n-hexane and ethyl acetate $(70: 30, v / v)$ at a flow rate of $1 \mathrm{~mL} / \mathrm{min}$. The compounds were 
identified by chromatographic comparisons with authentic standards. Quantification was based on the fluorescence signal response of each standard, using the IS (tocol) method and by using calibration curves obtained from commercial standards of each compound ( $\alpha-, \beta-, \gamma-$, and $\delta$-isoforms). The results were expressed as mg per $100 \mathrm{~g}$ of dry weight.

\subsubsection{Content of phenolic compounds}

Methanol/water extracts: Extracts were prepared from the whole plant, leaves and stems; each sample $(1 \mathrm{~g})$ was extracted three times with $30 \mathrm{~mL}$ of methanol/water 80:20 (v/v) at room temperature, $30 \mathrm{~g}$, for $1 \mathrm{~h}$. The extract was filtered through Whatman 4 paper (Sigma-aldrich, St. Louis, MO, USA). The residue was then re-extracted, with an additional $30 \mathrm{~mL}$ portion of methanol/water 80:20 (v/v). The combined extracts were evaporated under reduced pressure (rotary evaporator Büchi R-210, Flawil, Switzerland), until complete removal of methanol. The aqueous phase was lyophilized (FreeZone 4.5, Labconco, Kansas City, MO, USA).

Analysis of phenolic compounds. The extracts were analysed using a Hewlett-Packard 1100 chromatograph (Hewlett-Packard 1100, Agilent Technologies, Santa Clara, CA, US) with a quaternary pump and a diode array detector (DAD) coupled to an HP Chem Station (rev. A.05.04) data-processing station. A Waters Spherisorb S3 ODS-2 C18, 3 $\mu \mathrm{m}(4.6 \mathrm{~mm} \times 150 \mathrm{~mm})$ column thermostatted at $35{ }^{\circ} \mathrm{C}$ was used. The solvents used were: (A) $0.1 \%$ formic acid in water, (B) acetonitrile. The elution gradient established was isocratic $15 \%$ for $5 \mathrm{~min}, 15 \% \mathrm{~B}$ to $20 \%$ B over $5 \mathrm{~min}, 20-25 \%$ B over $10 \mathrm{~min}, 25$ $35 \% \mathrm{~B}$ over $10 \mathrm{~min}, 35-50 \%$ for $10 \mathrm{~min}$, and re-equilibration of the column, using a flow rate of $0.5 \mathrm{~mL} / \mathrm{min}$. Double online detection was carried out in the DAD using 
280, 330 and $370 \mathrm{~nm}$ as preferred wavelengths and in a mass spectrometer (MS) connected to HPLC system via the DAD cell outlet (Barros et al., 2013).

MS detection was performed in an API 3200 Qtrap (Applied Biosystems, Darmstadt, Germany) equipped with an ESI source and a triple quadrupole-ion trap mass analyzer that was controlled by the Analyst 5.1 software. Zero grade air served as the nebulizer gas (30 psi) and turbo gas for solvent drying (400 $\left.{ }^{\circ} \mathrm{C}, 40 \mathrm{psi}\right)$. Nitrogen served as the curtain (20 psi) and collision gas (medium). The quadrupols were set at unit resolution. The ion spray voltage was set at $-4500 \mathrm{~V}$ in the negative mode. The MS detector was programmed for recording in two consecutive modes: Enhanced MS (EMS) and enhanced product ion (EPI) analysis. EMS was employed to show full scan spectra, so as to obtain an overview of all of the ions in the sample. Settings used were: declustering potential (DP) $-450 \mathrm{~V}$, entrance potential (EP) $-6 \mathrm{~V}$, collision energy (CE) $10 \mathrm{~V}$. EPI mode was performed in order to obtain the fragmentation pattern of the parent ion(s) in the previous scan using the following parameters: DP $-50 \mathrm{~V}, \mathrm{EP}-6 \mathrm{~V}, \mathrm{CE}-$ $25 \mathrm{~V}$, and collision energy spread (CES) $0 \mathrm{~V}$. Spectra were recorded in negative ion mode between $\mathrm{m} / \mathrm{z} 100$ and 1000 .

The phenolic compounds were identified by comparing their retention times, UV-vis and mass spectra with those obtained with standard compounds, when available. Otherwise, compounds were tentatively identified comparing the obtained information with available data reported in the literature. For quantitative analysis, a calibration curve for each available phenolic standard (caffeic acid, chlorogenic acid, kaemferol-3$O$-rutinoside, quercetin-3-O-rutinoside, rosmarinic acid) was constructed based on the UV signal. For the identified phenolic compounds for which a commercial standard was not available, the quantification was performed through the calibration curve of another 
compound from the same phenolic group. The results were expressed as mg per $\mathrm{g}$ of extract.

\subsection{Evaluation of bioactive properties}

\subsubsection{General}

Methanol/water extracts (prepared according to the previous section) were re-dissolved in methanol/water $(80: 20, v / v, 1 \mathrm{mg} / \mathrm{mL}$ for antioxidant activity evaluation and 8 $\mathrm{mg} / \mathrm{mL}$ for anti-inflammatory and cytotoxicity screening). The final solutions were further diluted to different concentrations for being submitted to the following in vitro assays.

\subsubsection{Antioxidant activity}

DPPH radical-scavenging activity was evaluated by using an ELX800 microplate reader (Bio-Tek Instruments, Inc; Winooski, VT, USA), and calculated as a percentage of DPPH discoloration using the formula: $\left[\left(A_{D P P H}-A_{S}\right) / A_{D P P H}\right] \times 100$, where $A_{S}$ is the absorbance of the solution containing the sample at $515 \mathrm{~nm}$, and $A_{\mathrm{DPPH}}$ is the absorbance of the DPPH solution. Reducing power was evaluated by the capacity to convert $\mathrm{Fe}^{3+}$ into $\mathrm{Fe}^{2+}$, measuring the absorbance at $690 \mathrm{~nm}$ in the microplate reader mentioned above. Inhibition of $\beta$-carotene bleaching was evaluated through the $\beta$ carotene/linoleate assay; the neutralization of linoleate free radicals avoids $\beta$-carotene bleaching, which is measured by the formula: $\beta$-carotene absorbance after $2 \mathrm{~h}$ of assay/initial absorbance $) \times 100$. Inhibition of lipid peroxidation in porcine (Sus scrofa) brain homogenates was evaluated by the decrease in thiobarbituric acid reactive substances (TBARS); the color intensity of the malondialdehyde-thiobarbituric acid 
(MDA-TBA) was measured as its absorbance at $532 \mathrm{~nm}$; the inhibition ratio (\%) was calculated using the following formula: $[(\mathrm{A}-\mathrm{B}) / \mathrm{A}] \times 100 \%$, where $\mathrm{A}$ and $\mathrm{B}$ were the absorbance of the control and the sample solutions, respectively (Barros et al., 2013). Trolox was used as positive control and the results were expressed as $\mathrm{EC}_{50}$ values (sample concentration providing $50 \%$ of antioxidant activity or 0.5 of absorbance in the reducing power assay) in $\mu \mathrm{g}$ per $\mathrm{mL}$ of extract.

\subsubsection{Anti-inflammatory activity}

Cells treatment. For the anti-inflammatory activity assay, the methanolic extracts were dissolved in water, and concentrated to $8 \mathrm{mg} / \mathrm{mL}$. For the various assays, the extracts were then submitted to further dilutions from $8 \mathrm{mg} / \mathrm{mL}$ to $0.125 \mathrm{mg} / \mathrm{mL}$.

The mouse macrophage-like cell line RAW 264.7 was cultured in DMEM medium supplemented with $10 \%$ heat-inactivated foetal bovine serum, glutamine and antibiotics at $37{ }^{\circ} \mathrm{C}$ under $5 \% \mathrm{CO}_{2}$, in humidified air. For each experiment, cells were detached with a cell scraper. In the experiment cell density of $5 \times 10^{5}$ cells $/ \mathrm{mL}$ was used, and the proportion of dead cells was less than 5\% according to the Trypan blue dye exclusion test. Cells were seeded in 96-well plates at 150,000 cells/well and allowed do attach to the plate overnight. Subsequently, cells were treated with the various concentrations of each extract for $1 \mathrm{~h}$. Dexamethasone $(50 \mu \mathrm{M})$ was used as a positive control for the experiment. The following step was the stimulation with LPS $(1 \mu \mathrm{g} / \mathrm{mL})$ for $18 \mathrm{~h}$. The effect of all the tested samples in the absence of LPS was also evaluated, in order to observe if they induced changes in Nitric oxide (NO) basal levels. In negative controls, no LPS was added. Both extracts and LPS were dissolved in supplemented DMEM (Corrêa et al., 2015). 
Nitric oxide determination. For the determination of nitric oxide, a Griess Reagent System kit was used, which contains sulphanilamide, N-(1-napthyl)ethylenediamine hydrochloride (NED) and nitrite solutions. A reference curve of nitrite (sodium nitrite $100 \mu \mathrm{M}$ to $\left.1.6 \mu \mathrm{M} ; \mathrm{y}=0.0066 \mathrm{x}+0.1349 ; R^{2}=0.9986\right)$ was prepared in a 96 -well plate. The cell culture supernatant $(100 \mu \mathrm{L})$ was transferred to the plate and mixed with sulphanilamide and NED solutions, 5-10 minutes each, at room temperature. The nitric oxide produced was determined by measuring the absorbance at $540 \mathrm{~nm}$ (microplate reader ELX800 Biotek), and by comparison with the standard calibration curve (Corrêa et al., 2015). The results were expressed in $\mathrm{EC}_{50}$ values $(\mu \mathrm{g} / \mathrm{mL})$, which correspond to the sample concentration providing 50\% of inhibition of nitric oxide (NO) production.

\subsubsection{Cytotoxicity in human tumor cell lines}

Four human tumor cell lines were used: MCF-7 (breast adenocarcinoma), NCI-H460 (non-small cell lung cancer), HeLa (cervical carcinoma) and HepG2 (hepatocellular carcinoma). Cells were routinely maintained as adherent cell cultures in RPMI-1640 medium containing 10\% heat-inactivated FBS and $2 \mathrm{mM}$ glutamine (MCF-7, NCI-H460 HeLa and HepG2 cells), at $37{ }^{\circ} \mathrm{C}$, in a humidified air incubator containing $5 \% \mathrm{CO}_{2}$. Each cell line was plated at an appropriate density $\left(7.5 \times 10^{3}\right.$ cells/well for MCF-7 and NCI-H460 or $1.0 \times 10^{4}$ cells/well for HeLa and HepG2) in 96-well plates. The sulforhodamine B assay was performed according to a procedure previously described by the authors (Barros et al., 2013). Ellipticine was used as positive control and the results were expressed as $\mathrm{GI}_{50}$ values (sample concentration that inhibited $50 \%$ of the net cell growth) in $\mu \mathrm{g}$ per $\mathrm{mL}$.

\subsubsection{Cytotoxicity in non-tumor liver cells primary culture}


A cell culture was prepared from a freshly harvested porcine liver obtained from a local slaughter house, according to a procedure established by the authors (Abreu et al., 2011); it was designed as PLP2. Cultivation of the cells was continued with direct monitoring every two to three days using a phase contrast microscope. Before confluence was reached, cells were subcultured and plated in 96-well plates at a density of $1.0 \times 10^{4}$ cells/well, and commercial in DMEM medium with $10 \% \mathrm{FBS}, 100 \mathrm{U} / \mathrm{mL}$ penicillin and $100 \mu \mathrm{g} / \mathrm{mL}$ streptomycin. Ellipticine was used as positive control and the results were expressed as $\mathrm{GI}_{50}$ values (sample concentration that inhibited $50 \%$ of the net cell growth) in $\mu \mathrm{g}$ per $\mathrm{mL}$.

\subsection{Statistical analysis}

Three samples were used for each preparation and all the assays were carried out in triplicate. The results are expressed as mean values and standard deviations (SD). The results were analyzed using one-way analysis of variance (ANOVA) followed by Tukey's HSD test with $\alpha=0.05$. This treatment was carried out using the SPSS v. 22.0 program. 


\section{Results and discussion}

\subsection{Nutritionally characterization}

The I. paraguariensis whole plant, leaves and stems were nutritionally characterized, and the results are presented in Table 1. The stems showed the lowest content in fat, proteins and ash, however, the highest content in carbohydrates among the analyzed samples. The whole plant and leaves samples presented no statistical differences with respect to the protein and carbohydrate contents. Esmelindro, Toniazzo, Waczuk, Dariva \& Oliveira (2002) reported a similar value of ash content (6 g/100 g dw) for in natura yerba mate leaves dried with microwave. Berté, Beux, Spada, Salvador \& Hoffmann-Ribani (2011) also reported a similar value of fat content (4 g/ $100 \mathrm{~g} \mathrm{dw}$ ) for yerba mate dehydrated leaves, while Reis, de Souza, da Silva, Martins, Nunes \& Druzian (2015) found a higher value $(6 \mathrm{~g} / 100 \mathrm{~g} \mathrm{dw})$ in commercial yerba mate powder. However, the cited authors found distinct values with respect to protein and carbohydrate contents of I. paraguariensis leaves. As expected, all samples showed low energy density. No significant differences was found regarding the energetic contribution of whole plant and leaves samples $(1666 \mathrm{~kJ} / 100 \mathrm{~g} \mathrm{dw}$ and $1668 \mathrm{~kJ} / 100 \mathrm{~g}$ $\mathrm{dw}$, respectively), with a slightly inferior value corresponding to the stems sample.

The yerba mate samples of whole plant, leaves and stems were also characterized in terms of hydrophilic (Table 2) and lipophilic (Table 3) compounds.

Regarding the free sugars composition, it was possible to quantify five distinct compounds in the three samples: fructose, glucose, sucrose, trehalose and raffinose. The whole plant and leaves presented the highest content in total free sugars, with no statistical differences between them. However, the leaves showed the highest contents of sucrose, trehalose and raffinose, while the whole plant presented the highest content in glucose and the stems the highest levels of fructose. Chlamtac (1955), in a pioneer 
study, identified glucose, sucrose, raffinose and levulose in I. paraguariensis leaves. Besides, Reis et al. (2015) reported lower values of fructose and sucrose $(0.9 \mathrm{~g} / 100 \mathrm{~g}$ $\mathrm{dw}$ and $1.5 \mathrm{~g} / 100 \mathrm{~g} \mathrm{dw}$, respectively), added to a slightly higher content of glucose (1.3 $\mathrm{g} / 100 \mathrm{~g} \mathrm{dw}$ ) in yerba mate powder.

It was possible to quantify five different organic acids: oxalic, quinic, malic, ascorbic and citric acids (Table 2). The whole plant presented the highest content in all the identified organic acids, followed by the leaves and, finally, the stems. Arçari et al. (2011) also identified quinic acid in yerba mate using UPLC-MS. Though, as far as we know, data referring to I. paraguariensis organic acids profile are very scarce.

The percentages of the fatty acids detected in the yerba mate, including total saturated fatty acids (SFA), monounsaturated fatty acids (MUFA) and polyunsaturated fatty acids (PUFA) levels are shown in Table 3. Up to 18 fatty acids were detected and quantified, being $\alpha$-linolenic acid (C18:3n3, PUFA) the main fatty acid found in all samples. Nevertheless, the levels of this fatty acid found in the stems were considerably lower than those found for the whole plant and leaves, whereas the latter presented the highest content of this compound. The second major fatty acid detected was palmitic acid (C16:0, SFA), the stems presenting the highest content, followed by the whole plant. The studied yerba mate samples also showed relevant contents in linoleic (C18:2n6c, PUFA), oleic (C18:1n9, PUFA) and stearic (C18:0, SFA) acids. Reis et al. (2015) found a much higher content of palmitic acid (49\%), and consequently a lower content of $\alpha$ linolenic acid (34\%), in yerba mate powder. However, those authors reported an oleic acid level $(6.5 \%)$ similar to the one found for the herein studied stems. These differences could be related with the natural variability inherent to samples grown under different environmental conditions. 
In all I. paraguariensis samples, PUFA predominated over MUFA due to the significant contribution of $\alpha$-linolenic and linoleic acids. The leaves revealed the highest content in PUFA, while the stems presented the highest level of MUFA and SFA.

Over the last two decades, the two major indices used to evaluate nutritional quality of the lipid fraction of food have been the PUFA/SFA and n-6/n-3 ratios. A diet with low values of PUFA/SFA is not appropriate once it favours an increase in blood cholesterol. On the other hand, the $n-6 / n-3$ ratio is recommended to be low, in order to avoid the prothrombotic and proagregatory state induced by a high level of n-6 PUFA (Lira, Silva, Figueirêdo \& Bragagnolo, 2014). Thus, for health beneficial effects PUFA/SFA ratios should be higher than 0.45 , while $n-6 / n-3$ fatty acids ratios should be lower than 4.0 (Dias et al., 2014), as it is observed in the present study for all studied samples (Table 3).

However, the criterion of the PUFA/SFA and $n-6 / n-3$ ratios should not be considered alone because, among other factors, it does not take into account the beneficial effects of monounsaturated fatty acids and 18:0, in spite of the latter being a saturated fatty acid (Lira et al., 2014). For this reason, the IA and IT indices, as well as the ratio between $\mathrm{H} / \mathrm{H}$, were calculated for all the yerba mate samples (Table 3). The I. paraguariensis leaves showed the lowest values of both IA and IT indices, followed by the whole plant. Lower values of the couple IA and TI indices imply a better nutritional quality of the fatty acids; thus, diets with low IA and TI values could potentially diminish the risk of coronary heart disease (Filho, Ramos, Hiane \& Souza, 2010). Furthermore, the yerba mate leaves also presented the highest value of $\mathrm{h} / \mathrm{H}$ ratio among the tested samples, once again followed by the whole plant. Higher $\mathrm{h} / \mathrm{H}$ ratios are also considered advantageous (Hosseini et al. 2014), by virtue of the specific effects of fatty acids on cholesterol metabolism. 
Regarding the tocopherols composition, all I. paraguariensis samples presented only $\alpha$ tocopherol isoform (Table 3). The leaves showed the highest contents, while the stems presented a much lower level when compared with the other two samples. The presence of vitamin E in yerba mate leaves was also reported by Jacques, Freitas, Peres, Dariva, Oliveira \& Caramão (2006), although the levels were much lower $(8.3 \mathrm{mg} / 100 \mathrm{~g} \mathrm{dw})$ than those determined herein. Once more, the differences could be related with the different origin of the samples and inherent environmental conditions.

\subsection{Characterization of non-nutrients}

The phenolic chromatographic profile of $I$. paraguariensis leaves (methanol/water extract) recorded at 280 and $370 \mathrm{~nm}$ is shown in Figure 1. Compound characteristics, tentative identities and quantitative results are presented in Table 4. Eleven compounds were detected, nine of which were phenolic acids and two flavonol derivatives.

Compounds 5, 7 and 10 were positively identified as 5-O-caffeoylquinic acid (5-CQA, chlorogenic acid), quercetin-3-O-rutinoside (rutin) and kaempferol-3-O-rutinoside, respectively, by comparison with authentic standards, as also by their MS fragmentation patterns, retention times and UV-vis characteristics. Chlorogenic acid (5-CQA) and rutin have been extensively reported in I. paraguariensis by many authors (de Mejía et al., 2010; Isolabella et al., 2010; Berté et al 2011; Anesini, Turner, Cogoi \& Filip, 2012; Peres et al., 2013). Contents of 5-CQA (48 mg/g of extract) similar to those determined in our samples were reported by de Mejía et al. (2010) in aqueous extracts of Argentinean I. paraguariensis, whereas higher levels of rutin (ranging from $15-35$ $\mathrm{mg} / \mathrm{g}$ of extract) were found by the same authors in aqueous extracts of yerba mate from diverse countries. Rostagno et al. (2011) quantified the kaempferol-3-O-rutinoside (4.2 $\mathrm{mg} / \mathrm{L}$ of extract) in an aqueous extract of I. paraguariensis. 
Compound $1\left([\mathrm{M}-\mathrm{H}]^{-}\right.$at $\mathrm{m} / \mathrm{z}$ 353) was identified as 3-O-caffeoylquinic acid (neochlorogenic acid) based on its $\mathrm{MS}^{2}$ fragmentation, yielding the base peak at $\mathrm{m} / \mathrm{z} 191$ and the ion at $m / z 179$ with an intensity of $74 \%$ relative to the base peak, considered characteristic of 3-acylchlorogenic acids as reported by Clifford, Johnston, Knight \& Kuhnert (2005). Compound 4 was easily distinguished from the other two caffeoylquinic acids by its base peak at $\mathrm{m} / \mathrm{z} 173$ [quinic acid- $\mathrm{H}_{-} \mathrm{H}_{2} \mathrm{O}$ ], accompanied by a secondary fragment ion at $\mathrm{m} / z 179$ with approximately $73 \%$ abundance of base peak, which allowed identifying it as 4-O-caffeoylquinic acid according to the fragmentation pattern described by Clifford et al. (2005). These compounds have been previously reported in I. paraguariensis (de Mejía et al., 2010; Anesini et al., 2012; Peres et al., 2013). Contents of neo-chlorogenic acid ranging from 15.2 to $35.3 \mathrm{mg} / \mathrm{g}$ of extract were reported by de Mejía et al. (2010) in aqueous extracts of distinct I. paraguariensis samples.

Compounds 8, 9 and $11\left([\mathrm{M}-\mathrm{H}]^{-}\right.$at $m / z$ 515) were assigned to 3,4-O-, 3,5-O- and 4,5-Odicaffeoylquinic acids, respectively, based on their elution order, fragmentation pattern and relative abundances (Clifford et al., 2005). The fragmentation pattern of compound 9 was similar to the one previously reported by Clifford et al. (2005) for 3,5-Odicaffeoylquinic. The $\mathrm{MS}^{2}$ base peak was at $\mathrm{m} / z$ 353, produced by the loss of one of the caffeoyl moieties [M-H-caffeoyl], and subsequent fragmentation of this ion yielded the same fragments as 5-caffeoylquinic acid at $\mathrm{m} / \mathrm{z} 191,179$ and 135, although in this case with a comparatively more intense signal at $m / z 179$ [caffeic acid-H] $^{-}$( $89 \%$ base peak). Compounds 8 and 11 showed an intense signal for the fragment at $m / z 173$ [quinic acid$\left.\mathrm{H}-\mathrm{H}_{2} \mathrm{O}\right]^{-}$, which is characteristic of 4-acyl-caffeoylquinic acids. However, whereas compound 8 produced a relatively intense ion at $m / z 335$ [caffeoylquinic acid- $\left.\mathrm{H}-\mathrm{H}_{2} \mathrm{O}\right]^{-}$ (45\% of base peak), this was barely detectable (3\% of base peak) in compound 11 . 
According to Clifford et al. (2005), these features would allow assigning peaks 8 and 11 as 3,4-O-dicaffeoylquinic acid and 4,5-O-dicaffeoylquinic acid, respectively. These identifications were also confirmed by different authors who have studied $I$. paraguariensis preparations (Anesini et al., 2012; Peres et al., 2013).

The remaining three compounds were also assigned as caffeic acid derivatives as concluded from their fragmentation patterns showing characteristic signals at $m / z 179$, 161 and 135. The pseudomolecular ion of compound $3\left([\mathrm{M}-\mathrm{H}]^{-}\right.$at $\left.m / z 341\right)$ matched a caffeic acid hexoside. Compound $6\left([\mathrm{M}-\mathrm{H}]^{-}\right.$at $m / z$ 537) would fit the caffeic acid trimers salvianolic acids $\mathrm{H} / \mathrm{I}$ and lithospermic acid A, although salvianolic acid $\mathrm{H}$ and lithospermic acid A were discarded as possible identities because of their fragmentation pattern (Ruan, Li, Li, Luo \& Kong, 2012), different to the one observed herein. Thus, peak 6 was tentatively assigned as salvianolic acid I, a compound that had been already identified in samples of Salvia officinalis analyzed in our laboratory (Martins et al., 2015). Finally, no definite structure could be assigned to peak 2 ([M-H] $]^{-}$at $\left.m / z 375\right)$, which was just designated as a caffeic acid derivative. To the best of our knowledge, none of these compounds have been previously described in I. paraguariensis In general, among the analyzed samples, the leaves were the richest part of most of the detected phenolic compounds closely followed by the whole yerba mate plant, whereas the stems were much poorer.

Actually, yerba mate is known to be an especially rich source of caffeic acid derivatives and chlorogenic acids, which are considered responsible for potential bioactive properties. Bracesco et al. (2011) related them with free radical and metal scavenging capacities, modulation of gene expression of antioxidant enzymes and interference with glucose absorption, among other biological activities. Puangpraphant, Berhow, Vermillion, Potts \& de Mejia (2011) demonstrated that dicaffeoylquinic acids present in 
I. paraguariensis methanolic extracts can inhibit NF-jB nucleus translocation in macrophages and induce apoptosis by activating caspases- 8 and -3 in human colon cancer cells, what suggests that diCQAs in yerba mate could be potential cytotoxic agents.

\subsection{Bioactivity of the I. paraguariensis extracts}

The in vitro antioxidant, anti-inflammatory (NO production inhibition) and cytotoxic properties of the methanol/water extracts of yerba mate whole plant, leaves and stems were evaluated, and the results are given in Table 5.

The leaves extract revealed the highest reducing power, DPPH scavenging activity and lipid peroxidation inhibition in brain homogenates, followed by the whole plant extract that presented the highest $\beta$-carotene bleaching inhibition. However, the stems extracts showed the least intense antioxidant capacity in all assays, which correlates with their lower levels of phenolic compounds.

Several authors evaluated the antioxidant activity of $I$. paraguariensis extracts (de Mejía et al., 2010; Peres et al., 2013; Blum-Silva et al., 2015), though they have used different methods or expressed their results in distinct units, making it impossible to compare them with our results. Berté et al. (2011) reported a much lower DPPH scavenging activity for an aqueous spray-dried extract of yerba mate from Brazil $\left(\mathrm{EC}_{50}\right.$ value $2520 \mu \mathrm{g} / \mathrm{mL}$ ) than the one determined herein. Bassani, Nunes \& Granato (2014) attested that the total content of phenolic compounds was strongly correlated with the free radical scavenging activity towards DPPH radicals. Likewise, Anesini et al. (2012) showed that chlorogenic and caffeic acids as well as the flavonoid rutin present in aqueous extracts of $I$. paraguariensis samples contributed directly to the antioxidant activity detected, by preventing lipid peroxidation. Accordingly, the higher antioxidant 
capacity presented by the leaves extract in comparison with the other samples could be explained by its higher content in phenolic compounds (Table 4).

Ilex paraguariensis extracts revealed a dose-dependent potential anti-inflammatory activity, with a relevant decrease of nitric oxide (NO) production even in the presence of low concentrated extracts (data not shown). The stems extract showed the highest anti-inflammatory activity (lowest $\mathrm{EC}_{50}$ value), followed by the whole plant extract (Table 5). Owing to their lower level of phenolic compounds, the superior antiinflammatory capacity exhibited by the yerba mate stems could be supposed to be due to other phytochemicals rather than or in addition to phenolic compounds. Recently, several studies have proposed the use of I. paraguariensis aqueous extracts for management of obesity due to its action on reducing obesity-associated inflammation (Tsai et al., 2010; Arçari et al., 2011; Lima et al., 2014). Furthermore, Lanzetti et al. (2008) determined that I. paraguariensis aqueous extracts reduced acute lung inflammation in mice exposed to cigarette smoke, and Tsai et al. (2010) reported the potential anti-inflammatory and antimicrobial effect of yerba mate methanolic extracts against inflammation induced by Propionibacterium acnes. Puangpraphant \& de Mejia (2009), in assays carried out in human macrophages activated by lipo-polysaccharide (LPS) in the presence of crude extracts of I. paraguariensis and some of its phytochemicals, demonstrated that quercetin was the most potent inhibitor of proinflammatory responses as measured by the blocking of $\mathrm{COX}-2$, whereas yerba mate saponins $\left(\mathrm{IC}_{50}=20 \mu \mathrm{M}\right)$ and oleanolic acid $\left(\mathrm{IC}_{50}=80 \mu \mathrm{M}\right)$ significantly inhibited iNOS/NO pathways. According to those authors, the combination of quercetin/saponins resulted in a synergistic interaction inhibiting both nitric oxide (NO) and prostaglandin $2\left(\mathrm{PGE}_{2}\right)$ production. Interestingly, the crude extract did not present a potent antiinflammatory effect probably because of antagonistic effects with other compounds. 
Results on the effects of the assayed extracts of I. paraguariensis on the growth of four human tumor cell lines (MCF-7, NCI-H460, HeLa and HepG2) are presented in Table 5, expressed as concentrations that caused $50 \%$ of the cell growth inhibition $\left(\mathrm{GI}_{50}\right)$. The yerba mate stems extract was again the most potent against MCF-7 and HepG2 cell lines, while no statistical significant differences were found between samples against NCI-H460 and HeLa cells. Several investigations have been conducted on the anticancer potential of yerba mate tea, including comparisons with other teas such as green tea, and it is believed to possess high anticancer potential (Heck \& de Mejía, 2007). Some in vitro and animal tests (de Mejía et al., 2010; Puangpraphant et al., 2011; Boaventura et al., 2015a) demonstrated protective effects of I. paraguariensis extracts against colon and liver cancers. Ramirez-Mares, Chandra \& de Mejia (2004) conducted experiments using HepG2 cells to check whether the in vitro chemopreventive activity consists in cytotoxicity, TPA-induced ornithine decarboxylase (ODC) or quinone reductase (QR) activity. Additionally, the topoisomerase inhibitory activity was evaluated using Saccharomyces cereviseae. The results of this study, of great relevance if one considers that cytotoxicity is highly associated with anticancer activity, suggest that yerba mate exerts higher cytotoxicity against human liver cancer cells when compared to green tea. Rutin and quercetin are compounds that showed cytotoxic effects on HepG2 cells, and although they are found in small concentrations in $I$. paraguariensis, they integrate the diversity of flavonoids present in yerba mate that might contribute to its anticancer potential (Alía, Ramos, Mateos, Granado-Serrano, Bravo \& Goya, 2006). The $\mathrm{GI}_{50}$ values obtained in the present study would confirm the cytotoxic potential of yerba mate extracts of plant, leaves and stems against tumor cell lines. 
None of the tested extracts have shown toxicity against normal (non-tumor) porcine liver primary cells (Table 5; $\mathrm{GI}_{50}>400 \mu \mathrm{g} / \mathrm{mL}$ for PLP2).

Overall, the yerba mate whole plant and leaves gave more nutritionally valuable profiles than stems regarding free sugars, organic acids and fatty acids profiles. The leaves extract revealed the highest antioxidant potential, along with the highest contents in phenolic compounds. However, the stems extract presented the most pronounced NO production inhibitory activity and cytotoxic properties (lowest $\mathrm{GI}_{50}$ values), which indicate that other phytochemicals besides phenolic compounds are responsible for these properties.

Although the yerba mate extracts have been widely studied, this manuscript reports the distinct potentialities of each individual part of the plant. Therefore, according to the target application, a particular part of the I. paraguariensis plant might be more suitable for obtaining bioactive formulations. However, in-vivo studies should be performed in order to confirm the bioactivity results obtained in the present work.

\section{Acknowledgements}

The authors are grateful to Foundation for Science and Technology (FTC, Portugal) for financial support to CIMO (Pest-OE/AGR/UI0690/2014), L. Barros research contract ("Compromisso para a Ciência") and R.C. Calhelha grant (SFRH/BPD/68344/2010). R.C.G. Correa and A. H. P. Souza thank CAPES Foundation, Ministry of Education of Brazil (CAPES fellows, process numbers BEX 3974/14-6 and BEX 3972/14-03, respectively). The authors also thank to A. Fernandes for all the support in some of the laboratorial work. 


\section{References}

Abreu, R.M.V., Ferreira, I.C.F.R., Calhelha, R.C., Lima, R.T., Vasconcelos, M.H., Adega, F., Chaves, R., \& Queiroz, M.J.R.P. (2011). Anti-hepatocellular carcinoma activity using human HepG2 cells and hepatotoxicity of 6-substituted methyl 3-aminothieno[3,2-b]pyridine-2-carboxylate derivatives: In vitro evaluation, cell cycle analysis and QSAR studies. European Journal of Medicinal Chemistry, 46, 5800-5806.

Alía, M., Ramos, S., Mateos, R., Granado-Serrano, A. B., Bravo, L., \& Goya, L. (2006). Quercetin protects human hepatoma HepG2 against oxidative stress induced by tert-butyl hydroperoxide. Toxicology and Applied Pharmacology, 212, 110-118.

Anesini, C., Turner, S., Cogoi, L. \& Filip, R. (2012). Study of the participation of caffeineand polyphenols on the overall antioxidant activity of mate (Ilex paraguariensis). LWT - Food Science and Technology, 45, 299-304.

AOAC. (2005). Official methods of analysis of AOAC international. In W. Horwitz, \& G. Latimer (Eds.) (18th ed.). Gaithersburg, MD: AOAC International.

Arçari, D. P., Bartchewsky Jr., W., Santos, T. W., Oliveira, K. A., De Oliveira, C.C., Gotardo, E. M., Pedrazzoli, J. Jr., Gambero, A., Ferraz, L. F., Carvalho, P. O. \& Ribeiro M. L. (2011). Anti-inflammatory effects of yerba maté extract (Ilex paraguariensis) ameliorate insulin resistance in mice with high fat diet-induced obesity. Molecular and Cellular Endocrinology, 335, 110-115.

Barros, L., Pereira, E., Calhelha, R. C., Dueñas, M., Carvalho, A. M., Santos-Buelga, C. \& Ferreira, I. C. F. R. (2013). Bioactivity and chemical characterization in hydrophilic and lipophilic compounds of Chenopodium ambrosioides L. Journal of Functional Foods, 5, 1732-1740. 
Bassani, D. C., Nunes, D. S. \& Granato, D. (2014). Optimization of phenolics and flavonoids extraction conditions and antioxidant activity of roasted yerba-mate leaves (Ilex paraguariensis A. St. Hil., Aquifoliaceae) using response surface methodology. Academia Brasileira de Ciências, 86, 923-934.

Berté, K. A. S, Beux, M. R., Spada, P. K. W. D. S., Salvador, M. \& Hoffmann-Ribani, R. (2011). Chemical composition and antioxidant activity of yerba-mate (Ilex paraguariensis A.St.-Hil., Aquifoliaceae) extract as obtained by spray drying. Journal of Agricultural and Food Chemistry, 59, 5523-5527.

Boaventura, B. C. B., Amboni, R. D. M. C., da Silva, E. L., Prudencio, E. S., Pietro, P. F. D., Malta, L. G., Polinati, R. M., Liu, R. H. (2015a). Effect of in vitro digestion of yerba mate (Ilex paraguariensis A. St. Hil.) extract on the cellular antioxidant activity, antiproliferative activity and cytotoxicity toward HepG2 cells. Food Research International, doi.org/10.1016/j.foodres.2015.05.004.

Boaventura, B. C. B., da Silva, E. L., Liu, R. H., Prudêncio, E. S., Di Pietro, P. F., Becker, A. M. \& Amboni, R. D. M. C. (2015b). Effect of yerba mate (Ilex paraguariensis A. St. Hil.) infusion obtained by freeze concentration technology on antioxidant status of healthy individuals. LWT - Food Science and Technology, $62,948-954$.

Blum-Silva, C. H., Chaves, V. C., Schenkel, E. P., Coelho, G. C. \& Reginatto, F. H. (2015). The influence of leaf age on methylxanthines, total phenolic content, and free radical scavenging capacity of Ilex paraguariensis aqueous extracts. Revista Brasileira de Farmacognosia, 25, 1-6.

Bracesco, N., Sanchez, A. G., Contreras, V., Menini, T. \& Gugliucci, A. (2011). Recent advances on Ilex paraguariensis research: minireview. Journal of Ethnopharmacology, 136, 378-84. 
Branco, C. S., Scola, G., Rodrigues, A. D., Cesio, V., Laprovitera, M., Heinzen, H., Santos, M. T., Fank, B., Freitas, S. C. V., Coitinho, A. S. \& Salvador, M. (2013). Anticonvulsant, neuroprotective and behavioral effects of organic and conventional yerba mate (Ilex paraguariensis St. Hil.) on pentylenetetrazolinduced seizures in Wistar rats. Brain Research Bulletin, 92, 60-68.

Bravo, L., Mateos, R., Sarriá, B., Baeza, G., Lecumberri, E., Ramos, S. \& Goya, L. (2014). Hypocholesterolaemic and antioxidant effects of yerba mate (Ilex paraguariensis) in high-cholesterol fed rats. Fitoterapia, 92, 219-229.

Chlamtac, E. B. (1955). Sugars in Ilex paraguariensis. Boletin del Instituto de Quimica Argentina, 38, 17-24.

Clifford, M. N., Johnston, K.L., Knight, S., \& Kuhnert, N. A. (2005). Discriminating between the six isomers of dicaffeoylquinic acid by LC-MSn. Journal of Agricultural and Food Chemistry, 53, 3821-3832.

Corrêa, R.C.G., Souza, A.H.P., Calhelha, R.C., Barros, L., Glamoclija, J., Sokovic, M., Peralta, R.M., Bracht, A., Ferreira, I.C.F.R. (2015). Bioactive formulations prepared from fruiting bodies and submerged culture mycelia of the Brazilian edible mushroom Pleurotus ostreatoroseus Singer. Food \& Function, 6, 21552164.

de Mejía, E. G., Song, Y. S., Heck, C. I., \& Ramirez-Mares, M. (2010). Yerba mate tea (Ilex paraguariensis): Phenolic, antioxidant capacity and in vitro inhibition of colon cancer cell proliferation. Journal of Functional Foods, 2, 23-34.

de Morais, E. C., Stefanuto, A., Klein, G. A., Boaventura, B. C., de Andrade, F., Wazlawik, E., Di Pietro, P. F., Maraschin, M., da Silva, E. L. (2009). Consumption of yerba mate (Ilex paraguariensis) improves serum lipid parameters in healthy dyslipidemic subjects and provides an additional LDL- 
cholesterol reduction in individuals on statin therapy. Journal of Agriculture and Food Chemistry, 57, 8316-8324.

Dias, M. I., Barros, L., Dueñas, M., Alves, R. C., Oliveira, M. B. P. P., Santos-Buelga, C. \& Ferreira, I. C. F. R. (2014). Nutritional and antioxidant contributions of Laurus nobilis L. leaves: Would be more suitable a wild or a cultivated sample? Food Chemistry, 156, 339-346.

Esmelindro, M. C., Toniazzo, G., Waczuk, A., Dariva, C. \& Oliveira, D. (2002). Caracterização físico-química da erva-mate: influência das etapas do processamento industrial. Food Science and Technology (Campinas), 22, 193204.

Farzaneh, V. \& Carvalho, I. S. (2015).A review of the health benefit potentials of herbal plant infusions and their mechanism of actions. Industrial Crops and Products, $65,247-258$.

Filho, M. M. R., Ramos, M. I. L., Hiane, P. A. \& Souza, E. M. T. D. (2010). Nutritional value of seven freshwater fish species from the Brazilian Pantanal. Journal of the American Oil Chemists' Society, 87, 1461-1467.

Gil-Chávez, G. J., Villa, J.A., Ayala-Zavala, J. F., Heredia, J. B., Sepulveda, D., Yahia, E. M. \& González-Aguilar, G. A. (2013).Technologies for Extraction and Production of Bioactive Compounds to be Used as Nutraceuticals and Food Ingredients: An Overview. Comprehensive Reviews in Food Science and Food Safety, 12, 5-23.

Heck, C. I. \& de Mejía, E. G. (2007). Yerba Mate Tea (Ilex paraguariensis): A Comprehensive Review on Chemistry, Health Implications, and Technological Considerations. Journal of Food Science, 72, R138-R151. 
Hosseini, H., Mahmoudzadeh, M., Rezaei, M., Mahmoudzadeh, L., Khaksar, R., Khosroshahi, N. K. \& Babakhani, A. (2014). Effect of different cooking methods on minerals, vitamins and nutritional quality indices of kutum roach (Rutilus frisii kutum). Food Chemistry, 148, 86-91.

Isolabella, S., Cogoi, L., López, P., Anesini, C., Ferraro, C. \& Filip, R. (2010). Study of the bioactive compounds variation during yerba mate (Ilex paraguariensis) processing. Food Chemistry, 122, 695-699.

Jacques, R. A., Freitas, L. S., Peres, V. F., Dariva, C., Oliveira, J. V. \& Caramão, E. B. (2006). Chemical composition of mate tea leaves (Ilex paraguariensis): A study of extraction methods. Journal of Separation Science, 29, 2780-2784.

Lanzetti, M., Bezerra, F. S., Romana-Souza, B. A., Brando-Lima, A. C., Koatz, V. L. G., Porto, L. C. \& Valenca, S. S. (2008). Mate tea reduced acute lung inflammation in mice exposed to cigarette smoke. Nutrition, 24, 375-381.

Lanzetti, M., Barroso, M. V., Nesi, R. T., Lopes, A. A., Trajano, E. T. L., Alves, J. N., Brogliato, A. R., Borges, P. A., Benjamim, C. F., Porto, L. C. \& Valenca, S. S. (2012). Ready-to-drink matte ${ }^{\circledR}$ tea shows anti-inflammatory and antioxidant properties on a cigarette smoke exposure model. Food Research International, 48, 798-801.

Lima, N. S., Oliveira, E., Silva, A. P. S., Maia, L. A., Moura, E. G. \& Lisboa, P. C (2014). Effects of Ilex paraguariensis (yerba mate) treatment on leptin resistance and inflammatory parameters in obese rats primed by early weaning. Life Sciences, 115, 29-35.

Lira, G. M., Silva K. W. B., Figueirêdo, B. C. \& Bragagnolo, N. (2014). Impact of smoking on the lipid fraction and nutritional value of seabob shrimp 
(Xiphopenaeus kroyeri, Heller, 1862). LWT - Food Science and Technology, 58, 183-187.

Márquez, V., Martínez, N., Guerra, M., Fariña, L., Boido, E. \& Dellacassa, E. (2013). Characterization of aroma-impact compounds in yerba mate (Ilex paraguariensis) using GC-olfactometry and GC-MS. Food Research International, 53, 808-815.

Martin, J. G. P., Porto, E., Alencar, S. M., Glória, E. M., Corrêa, C. B. \& Cabral, I. S. R. (2013). Antimicrobial activity of yerba mate (Ilex paraguariensis St. Hil.) against food pathogens. Revista Argentina de Microbiología, 45, 93-98.

Martins M., Barros L., Santos-Buelga C., Henriques M., Silva S., Ferreira I.C.F.R. (2015). Evaluation of bioactive properties and phenolic compounds in different extracts prepared from Salvia officinalis L. Food Chemistry, 170: 378-385.

Peres, R. G., Tonin, F. G., Tavares, M. F. M. \& Rodriguez-Amaya, D. B. (2013). HPLC-DAD-ESI/MS identification and quantification of phenolic compounds in Ilex paraguariensis beverages and on-line evaluation of individual antioxidant activity. Molecules, 18, 3859-3871.

Puangpraphant, S. \& de Mejia, E. G. (2009). Saponins in yerba mate tea (Ilex paraguariensis A. St.-Hil) and quercetin synergistically inhibit iNOS and COX-2 in lipopolysaccharide-induced macrophages through NFkB pathways. Journal of Agricultura and Food Chemistry, 57, 8873-8883.

Puangpraphant, S., Berhow, M. A., Vermillion, K., Potts, G. \& de Mejia, E. G. (2011). Dicaffeoylquinic acids in yerba mate (Ilex paraguariensis St. Hilaire) inhibit NF$\mathrm{jB}$ nucleus translocation in macrophages and induce apoptosis by activating caspases-8 and -3 in human colon cancer cells. Molecular Nutrition \& Food Research, 55, 1509-1522. 
Ramirez-Mares, M. V., Chandra, S. \& de Mejia, E. G. (2004). In vitro chemopreventive activity of Camellia sinensis, Ilex paraguariensis and Ardisia compressa tea extracts and selected polyphenols. Mutation Research, 554, 53-65.

Reis, L. C. B., de Souza, C. O., da Silva, J. B. A, Martins, A. C., Nunes, I. L. \& Druzian, J. I. (2015). Active biocomposites of cassava starch: The effect of yerba mate extract and mango pulp as antioxidant additives on the properties and the stability of a packaged product. Food and Bioproducts Processing, 94, 382-39.

Rostagno, M. A., Manchón, N., D’Arrigo, M., Guillamón, E., Villares, A., GarcíaLafuente, A., Ramos, A. \& Martínez J. A. (2011). Fast and simultaneous determination of phenolic compounds and caffeine in teas, mate, instant coffee, soft drink and energetic drink by high-performance liquid chromatography using a fused-core column. Analytica Chimica Acta, 685, 204-211.

Ruan, M., Li, Y., Li, X., Luo, J. \& Kong, L. (2012). Qualitative and quantitative analysis of the major constituents in Chinese medicinal preparation Guan-XinNing injection by HPLC-DAD-ESI-MS ${ }^{n}$. Journal of Pharmaceutical and Biomedical Analysis, 59, 184-189.

Santos-Silva, J., Bessa, R. J. B. \& Santos-Silva F. (2002). Effect of genotype, feeding system and slaughter weight on the quality of light lambs. II. Fatty acid composition of meat. Livestock Production Science, 77, 187-194.

Tamura, A., Sasakia, M., Yamashita, H., Matsui-Yuasa, I., Saku, T., Hikima, T., Tabuchi, M., Munakata, H. \& Kojima-Yuasa, A. (2013). Yerba-mate (Ilex paraguariensis) extract prevents ethanol-induced liver injury in rats. Journal of Functional Foods, 5, 1714-1723. 
Tsai, T-H., Tsai, T-H., Wuc, W-H., Tseng, JT-P. \& Tsai, P-J. (2010). In vitro antimicrobial and anti-inflammatory effects of herbs against Propionibacterium acnes. Food Chemistry, 119, 964-968.

Ulbricht, T. L. V. \& Southgate, D. A. T. (1991). Coronary heart disease: seven dietary factors. The Lancet, 338, 985-992. 
Table 1. Macronutrients composition $(\mathrm{g} / 100 \mathrm{~g} \mathrm{dw})$ and energetic value $(\mathrm{kJ} / 100 \mathrm{~g} \mathrm{dw})$ of Ilex paraguariensis (mean $\pm \mathrm{SD}$ ).

\begin{tabular}{lccc}
\hline & Whole plant & Leaves & Stems \\
\hline Ash & $6.00^{\mathrm{b}} \pm 0.01$ & $6.6^{\mathrm{a}} \pm 0.1$ & $4.5^{\mathrm{c}} \pm 0.1$ \\
Proteins & $26^{\mathrm{a}} \pm 1$ & $26.1^{\mathrm{a}} \pm 0.1$ & $20.8^{\mathrm{b}} \pm 0.4$ \\
Fat & $4.5^{\mathrm{b}} \pm 0.1$ & $4.9^{\mathrm{a}} \pm 0.1$ & $1.7^{\mathrm{c}} \pm 0.1$ \\
Carbohydrates & $63.5^{\mathrm{b}} \pm 1$ & $62.4^{\mathrm{b}} \pm 0.1$ & $73^{\mathrm{a}} \pm 1$ \\
Energy & $1666^{\mathrm{a}} \pm 14$ & $1668^{\mathrm{a}} \pm 4$ & $1637^{\mathrm{b}} \pm 7$
\end{tabular}

dw- dry weight. Means followed by the same letters in rows do not differ by the Tukey's test $(p<0.05)$. 
Table 2. Chemical composition in hydrophilic compounds (sugars and organic acids; $\mathrm{g} / 100 \mathrm{~g} \mathrm{dw}$ ) of Ilex paraguariensis (mean $\pm \mathrm{SD}$ ).

\begin{tabular}{lccc}
\hline Sugars & Whole plant & Leaves & Stems \\
\hline Fructose & $0.56^{\mathrm{b}} \pm 0.03$ & $0.43^{\mathrm{c}} \pm 0.01$ & $0.67^{\mathrm{a}} \pm 0.02$ \\
Glucose & $1.1^{\mathrm{a}} \pm 0.1$ & $1.06^{\mathrm{c}} \pm 0.01$ & $1.1^{\mathrm{b}} \pm 0.1$ \\
Sucrose & $4.8^{\mathrm{b}} \pm 0.3$ & $4.88^{\mathrm{a}} \pm 0.02$ & $3.6^{\mathrm{c}} \pm 0.3$ \\
Trehalose & $0.48^{\mathrm{b}} \pm 0.04$ & $0.52^{\mathrm{a}} \pm 0.01$ & $0.09^{\mathrm{c}} \pm 0.01$ \\
Raffinose & $0.28^{\mathrm{b}} \pm 0.02$ & $0.31^{\mathrm{a}} \pm 0.01$ & $0.17^{\mathrm{c}} \pm 0.01$ \\
Sum & $7.2^{\mathrm{a}} \pm 0.3$ & $7.20^{\mathrm{a}} \pm 0.02$ & $5.6^{\mathrm{b}} \pm 0.3$ \\
\hline Organic acids & & & \\
\hline Oxalic acid & $1.18^{\mathrm{a}} \pm 0.02$ & $0.79^{\mathrm{b}} \pm 0.02$ & $0.71^{\mathrm{c}} \pm 0.01$ \\
Quinic acid & $0.056^{\mathrm{a}} \pm 0.001$ & $0.017^{\mathrm{b}} \pm 0.001$ & $0.006^{\mathrm{c}} \pm 0.001$ \\
Malic acid & $1.60^{\mathrm{a}} \pm 0.04$ & $0.98^{\mathrm{b}} \pm 0.03$ & $0.59^{\mathrm{c}} \pm 0.01$ \\
Ascorbic acid & $2.8^{\mathrm{a}} \pm 0.1$ & $1.8^{\mathrm{b}} \pm 0.1$ & $1.31^{\mathrm{c}} \pm 0.01$ \\
Citric acid & $4.5^{\mathrm{a}} \pm 0.1$ & $2.8^{\mathrm{b}} \pm 0.1$ & $1.91^{\mathrm{c}} \pm 0.02$ \\
Sum & $10.1^{\mathrm{a}} \pm 0.2$ & $6.4^{\mathrm{b}} \pm 0.1$ & $4.54^{\mathrm{c}} \pm 0.01$ \\
\hline
\end{tabular}

dw- dry weight. Means followed by the same letters in rows do not differ by the Tukey's test $(p<0.05)$. 
Table 3. Chemical composition in lipophilic compounds (fatty acids, relative percentage, and tocopherols, $\mathrm{mg} / 100 \mathrm{~g} \mathrm{dw}$ ) of Ilex paraguariensis (mean $\pm \mathrm{SD}$ ).

\begin{tabular}{|c|c|c|c|}
\hline & Whole plant & Leaves & Stems \\
\hline C6:0 & $0.08^{\mathrm{b}} \pm 0.01$ & $0.07^{\mathrm{c}} \pm 0.01$ & $0.19^{\mathrm{a}} \pm 0.02$ \\
\hline C8:0 & $0.044^{\mathrm{b}} \pm 0.001$ & $0.042^{\mathrm{b}} \pm 0.001$ & $0.097^{\mathrm{a}} \pm 0.001$ \\
\hline C10:0 & $0.10^{\mathrm{b}} \pm 0.01$ & $0.06^{\mathrm{c}} \pm 0.01$ & $0.18^{\mathrm{a}} \pm 0.02$ \\
\hline C12:0 & $0.20^{\mathrm{b}} \pm 0.01$ & $0.15^{\mathrm{c}} \pm 0.01$ & $0.36^{\mathrm{a}} \pm 0.04$ \\
\hline C14:0 & $1.24^{\mathrm{b}} \pm 0.01$ & $0.96^{\mathrm{c}} \pm 0.04$ & $1.4^{\mathrm{a}} \pm 0.1$ \\
\hline C15:0 & $1.00^{\mathrm{a}} \pm 0.03$ & $0.4^{\mathrm{c}} \pm 0.1$ & $0.5^{\mathrm{b}} \pm 0.1$ \\
\hline C16:0 & $23.1^{\mathrm{b}} \pm 0.1$ & $20.7^{\mathrm{c}} \pm 0.4$ & $25.2^{\mathrm{a}} \pm 1.8$ \\
\hline C16:1 & $0.31^{\mathrm{c}} \pm 0.01$ & $0.36^{\mathrm{a}} \pm 0.02$ & $0.33^{\mathrm{b}} \pm 0.04$ \\
\hline C17:0 & $0.74^{\mathrm{b}} \pm 0.01$ & $0.7^{\mathrm{b}} \pm 0.1$ & $1.1^{\mathrm{a}} \pm 0.1$ \\
\hline C18:0 & $2.6^{\mathrm{c}} \pm 0.1$ & $2.6^{\mathrm{b}} \pm 0.1$ & $4.6^{\mathrm{a}} \pm 0.3$ \\
\hline C18:1n-9 & $3.2^{\mathrm{c}} \pm 0.1$ & $3.76^{\mathrm{b}} \pm 0.01$ & $7^{\mathrm{a}} \pm 1$ \\
\hline$C 18: 2 n-6$ & $7.44^{\mathrm{b}} \pm 0.01$ & $6.1^{\mathrm{c}} \pm 0.1$ & $15^{\mathrm{a}} \pm 1$ \\
\hline C18:3n-3 & $55.9^{\mathrm{b}} \pm 0.2$ & $60.3^{\mathrm{a}} \pm 0.3$ & $40^{c} \pm 4$ \\
\hline C20:0 & $0.6^{\mathrm{b}} \pm 0.1$ & $0.47^{\mathrm{c}} \pm 0.01$ & $0.64^{\mathrm{a}} \pm 0.01$ \\
\hline C22:0 & $0.8^{\mathrm{c}} \pm 0.1$ & $0.9^{\mathrm{b}} \pm 0.1$ & $1.16^{\mathrm{a}} \pm 0.01$ \\
\hline $\mathrm{C} 23: 0$ & $0.27^{\mathrm{b}} \pm 0.01$ & $0.27^{\mathrm{b}} \pm 0.01$ & $0.44^{\mathrm{a}} \pm 0.02$ \\
\hline $\mathrm{C} 24: 0$ & $0.84^{\mathrm{a}} \pm 0.04$ & $0.63^{\mathrm{b}} \pm 0.01$ & $0.6^{\mathrm{c}} \pm 0.1$ \\
\hline $\mathrm{C} 24: 1$ & $1.7^{\mathrm{a}} \pm 0.1$ & $1.51^{\mathrm{b}} \pm 0.04$ & $0.97^{\mathrm{c}} \pm 0.02$ \\
\hline \multicolumn{4}{|c|}{ Sums and ratios of fatty acids } \\
\hline SFA & $31.5^{\mathrm{b}} \pm 0.2$ & $28.0^{c} \pm 0.4$ & $37^{\mathrm{a}} \pm 2$ \\
\hline MUFA & $5.2^{\mathrm{c}} \pm 0.2$ & $5.6^{\mathrm{b}} \pm 0.1$ & $8^{\mathrm{a}} \pm 1$ \\
\hline PUFA & $63.3^{\mathrm{b}} \pm 0.2$ & $66.4^{\mathrm{a}} \pm 0.3$ & $55^{\mathrm{c}} \pm 4$ \\
\hline$n-6$ & $7.44^{\mathrm{b}} \pm 0.01$ & $6.1^{\mathrm{c}} \pm 0.1$ & $15^{\mathrm{a}} \pm 1$ \\
\hline$n-3$ & $55.9^{\mathrm{b}} \pm 0.2$ & $60.4^{\mathrm{a}} \pm 0.3$ & $40^{\mathrm{c}} \pm 4$ \\
\hline PUFA:SFA & $2.01^{\mathrm{b}} \pm 0.01$ & $2.38^{\mathrm{a}} \pm 0.01$ & $1.5^{\mathrm{c}} \pm 0.1$ \\
\hline$n-6: n-3$ & $0.13^{\mathrm{b}} \pm 0.01$ & $0.10^{\mathrm{c}} \pm 0.01$ & $0.4^{\mathrm{a}} \pm 0.1$ \\
\hline \multicolumn{4}{|c|}{ Indices of the nutritional quality of the lipid fraction } \\
\hline IA & $0.4^{\mathrm{b}} \pm 0.1$ & $0.3^{\mathrm{c}} \pm 0.1$ & $0.5^{\mathrm{a}} \pm 0.2$ \\
\hline IT & $0.15^{\mathrm{b}} \pm 0.04$ & $0.1^{\mathrm{c}} \pm 0.1$ & $0.2^{\mathrm{a}} \pm 0.2$ \\
\hline $\mathrm{HH}$ & $2.74^{\mathrm{b}} \pm 0.02$ & $3.2^{\mathrm{a}} \pm 0.1$ & $2.3^{\mathrm{c}} \pm 0.2$ \\
\hline$\alpha$-Tocopherol & $71^{\mathrm{b}} \pm 1$ & $78^{\mathrm{a}} \pm 3$ & $18^{\mathrm{c}} \pm 1$ \\
\hline
\end{tabular}

The results of fatty acids are expressed in relative percentage; the results of tocopherols are expressed in dry weight (dw) basis. Caproic acid (C6:0); Caprylic acid (C8:0); Capric acid (C10:0); Lauric acid (C12:0); Myristic acid (C14:0); Pentadecanoic acid (C15:0); Palmitic acid (C16:0); Palmitoleic acid (C16:1); Heptadecanoic acid (C17:0); Stearic acid (C18:0); Oleic acid (C18:1n9); Linoleic acid (C18:2n6c); $\alpha$-Linolenic acid (C18:3n3); Arachidic acid (C20:0); Behenic acid (C22:0); Tricosanoic acid (C23:0); Lignoceric acid (C24:0) and Nervonic acid (C24:1). Means followed by the same letters in rows do not differ by the Tukey's test $(p<0.05)$. SFA: total saturated fatty acids; MUFA: total monounsaturated fatty acids; PUFA: total polyunsaturated fatty acids; $n-6$ : total omega- 6 fatty acids; $n-3$ : total omega-3 fatty acids; IA: index of atherogenicity; IT: index of thrombogenicity; HH: hypocholesterolemic/hypercholesterolemic fatty acid ratio. 
Table 4. Retention time (Rt), wavelengths of maximum absorption in the visible region $\left(\lambda_{\max }\right)$, mass spectral data, identification and quantification of phenolic compounds (mg/g extract) in Ilex paraguariensis methanol/water extracts (mean $\pm \mathrm{SD})$.

\begin{tabular}{|c|c|c|c|c|c|c|c|c|}
\hline \multirow[b]{2}{*}{ Compound } & \multirow{2}{*}{$\begin{array}{l}\text { Rt } \\
(\min )\end{array}$} & \multirow[b]{2}{*}{$\begin{array}{l}\lambda_{\max } \\
(\mathrm{nm})\end{array}$} & \multirow{2}{*}{$\begin{array}{l}\text { Molecular ion } \\
{[\mathrm{M}-\mathrm{H}]^{-}(\mathrm{m} / \mathrm{z})}\end{array}$} & \multirow{2}{*}{$\begin{array}{l}\mathrm{MS}^{2} \\
(m / z)\end{array}$} & \multirow[b]{2}{*}{ Tentative identification } & \multicolumn{3}{|c|}{ Quantification } \\
\hline & & & & & & $\begin{array}{l}\text { Whole } \\
\text { plant }\end{array}$ & Leaves & Stems \\
\hline 1 & 5.0 & 328 & 353 & 191(100),179(74),173(7),161(7),135(37) & 3-O-Caffeoylquinic acid & $53.4^{\mathrm{b}} \pm 0.4$ & $64.3^{\mathrm{a}} \pm 0.2$ & $32.7^{\mathrm{c}} \pm 0.1$ \\
\hline 2 & 5.5 & 272,320 & 375 & 201(31),179(22),161(11),135(24) & Caffeic acid derivative & $\begin{array}{l}8.46^{\mathrm{b}} \pm 0.0 \\
4\end{array}$ & $8.9^{\mathrm{a}} \pm 0.1$ & $3.8^{\mathrm{c}} \pm 0.1$ \\
\hline 3 & 6.0 & 328 & 341 & $179(100), 161(50), 135(54)$ & Caffeic acid hexoside & $2.3^{\mathrm{b}} \pm 0.1$ & $2.57^{\mathrm{a}} \pm 0.03$ & $1.12^{\mathrm{c}} \pm 0.04$ \\
\hline 4 & 6.9 & 328 & 353 & $191(20), 179(73), 173(100), 161(4), 135(15)$ & 4-O-Caffeoylquinic acid & $24.3^{\mathrm{a}} \pm 0.6$ & $25.6^{\mathrm{a}} \pm 0.4$ & $21.8^{\mathrm{b}} \pm 0.3$ \\
\hline 5 & 7.5 & 328 & 353 & 191(100),179(48),173(49),161(22),135(28) & 5-O-Caffeoylquinic acid & $47^{\mathrm{a}} \pm 1$ & $44.7^{\mathrm{b}} \pm 0.2$ & $43.1^{\mathrm{c}} \pm 0.1$ \\
\hline 6 & 11.5 & $232,274,320$ & 537 & $519(44), 341(3), 179(11), 161(28), 135(4)$ & Salvianolic acid I & $41.1^{\mathrm{b}} \pm 0.4$ & $43.1^{\mathrm{a}} \pm 0.3$ & $21.3^{\mathrm{c}} \pm 0.2$ \\
\hline 7 & 18.4 & 354 & 609 & $301(100)$ & Quercetin-3-O-rutinoside & $11.1^{\mathrm{b}} \pm 0.1$ & $12.66^{\mathrm{a}} \pm 0.01$ & $2.81^{\mathrm{c}} \pm 0.02$ \\
\hline 8 & 19.7 & 328 & 515 & $353(87), 335(45), 191(41), 179(76), 173(91), 161(17), 135(25)$ & 3,4-O-Dicaffeoylquinic acid & $17.7^{\mathrm{a}} \pm 0.2$ & $17.1^{\mathrm{a}} \pm 0.4$ & $10.3^{\mathrm{b}} \pm 0.4$ \\
\hline 9 & 21.5 & 328 & 515 & $353(90), 335(8), 191(100), 179(89), 173(14), 161(8), 135(46)$ & 3,5-O-Dicaffeoylquinic acid & $60^{\mathrm{a}} \pm 1$ & $60^{\mathrm{a}} \pm 1$ & $29.9^{\mathrm{b}} \pm 0.4$ \\
\hline 10 & 21.8 & 348 & 593 & $285(100)$ & Kaempferol-3-O-rutinoside & $5.7^{\mathrm{a}} \pm 0.3$ & $5.99^{\mathrm{a}} \pm 0.02$ & $0.25^{\mathrm{b}} \pm 0.01$ \\
\hline \multirow[t]{3}{*}{11} & 24.1 & 328 & 515 & $353(95), 335(3), 191(28), 179(73), 173(100), 161(6), 135(24)$ & 4,5-O-Dicaffeoylquinic acid & $27.2^{\mathrm{a}} \pm 0.4$ & $24.0^{\mathrm{b}} \pm 0.1$ & $21.2^{\mathrm{c}} \pm 0.1$ \\
\hline & & & & & Total phenolic acids & $281^{\mathrm{b}} \pm 2$ & $290^{\mathrm{a}} \pm 1$ & $185^{\mathrm{c}} \pm 1$ \\
\hline & & & & & Total flavonoids & $16.8^{\mathrm{b}} \pm 0.4$ & $18.56^{\mathrm{a}} \pm 0.02$ & $3.06^{\mathrm{c}} \pm 0.01$ \\
\hline
\end{tabular}


Table 5. Bioactive properties of Ilex paraguariensis methanol/water extracts (mean $\pm \mathrm{SD}$ ).

\begin{tabular}{|c|c|c|c|}
\hline & ple plant & aves & $\mathrm{ms}$ \\
\hline \multicolumn{4}{|c|}{ Antioxidant activity $\left(\mathrm{EC}_{50}\right.$ values, $\left.\mu \mathrm{g} / \mathrm{mL}\right)$} \\
\hline DPPH scavenging activity & $123^{\mathrm{b}} \pm 1$ & $112^{\mathrm{c}} \pm 5$ & $213^{\mathrm{a}} \pm 15$ \\
\hline Reducing power & $50^{\mathrm{b}} \pm 1$ & $46^{\mathrm{c}} \pm 2$ & $90^{\mathrm{a}} \pm 4$ \\
\hline$\beta$-carotene beaching inhibition & $316^{\mathrm{c}} \pm 26$ & $447^{\mathrm{b}} \pm 18$ & $638^{\mathrm{a}} \pm 6$ \\
\hline TBARS inhibition & $61^{\mathrm{b}} \pm 1$ & $60^{\mathrm{c}} \pm 3$ & $290^{\mathrm{a}} \pm 24$ \\
\hline \multicolumn{4}{|c|}{ Anti-inflammatory activity $\left(\mathrm{EC}_{50}\right.$ values, $\left.\mu \mathrm{g} / \mathrm{mL}\right)$} \\
\hline Nitric oxide (NO) production & $28^{\mathrm{b}} \pm 1$ & $30.0^{\mathrm{a}} \pm 0.3$ & $26^{\mathrm{c}} \pm 1$ \\
\hline \multicolumn{4}{|c|}{ Cytotoxicity to tumor cell lines ( $\left(\mathrm{GI}_{50}\right.$ values, $\left.\mu \mathrm{g} / \mathrm{mL}\right)$} \\
\hline MCF-7 (breast carcinoma) & $273^{\mathrm{a}} \pm 17$ & $247^{\mathrm{ab}} \pm 15$ & $241^{\mathrm{b}} \pm 6$ \\
\hline NCI-H460 (non-small cell lung cancer) & $242^{\mathrm{a}} \pm 7$ & $233^{\mathrm{a}} \pm 21$ & $229^{\mathrm{a}} \pm 11$ \\
\hline HeLa (cervical carcinoma) & $262^{\mathrm{a}} \pm 23$ & $270^{\mathrm{a}} \pm 8$ & $294^{\mathrm{a}} \pm 10$ \\
\hline HepG2 (hepatocellular carcinoma) & $288^{\mathrm{a}} \pm 12$ & $273^{\mathrm{a}} \pm 2$ & $206^{\mathrm{b}} \pm 12$ \\
\hline
\end{tabular}

Cytotoxicity to non-tumor cells $\left(\mathrm{GI}_{50}\right.$ values, $\left.\mu \mathrm{g} / \mathrm{mL}\right)$

$\begin{array}{llll}\text { PLP2 growth inhibition } & >400 & >400 & >400\end{array}$

The antioxidant activity was expressed as $\mathrm{EC}_{50}$ values, what means that higher values correspond to lower reducing power or antioxidant potential. EC $\mathrm{C}_{50}$ : Extract concentration corresponding to $50 \%$ of antioxidant activity or 0.5 of absorbance in reducing power assay. Trolox EC 50 values: $41 \mu \mathrm{g} / \mathrm{mL}$ (reducing power), $42 \mu \mathrm{g} / \mathrm{mL}$ (DPPH scavenging

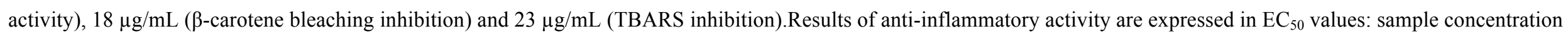
providing $50 \%$ of inhibition of nitric oxide (NO) production. Dexamethasone $\mathrm{EC}_{50}$ value: $16 \pm 2 \mu \mathrm{g} / \mathrm{mL}$.Cytotoxicity results are expressed in $\mathrm{GI}_{50}$ values corresponding to the sample concentration achieving $50 \%$ of growth inhibition in human tumor cell lines or in liver primary culture PLP2. Ellipticine GI 50 values: $1.2 \mu \mathrm{g} / \mathrm{mL}(\mathrm{MCF}-7), 1.0 \mu \mathrm{g} / \mathrm{mL}$ (NCI-H460), $0.91 \mu \mathrm{g} / \mathrm{mL}$ (HeLa), $1.1 \mu \mathrm{g} / \mathrm{mL}$ (HepG2) and 2.3 (PLP2).Means followed by the same letters in rows do not differ by the Tukey's test $(p<0.05)$. 


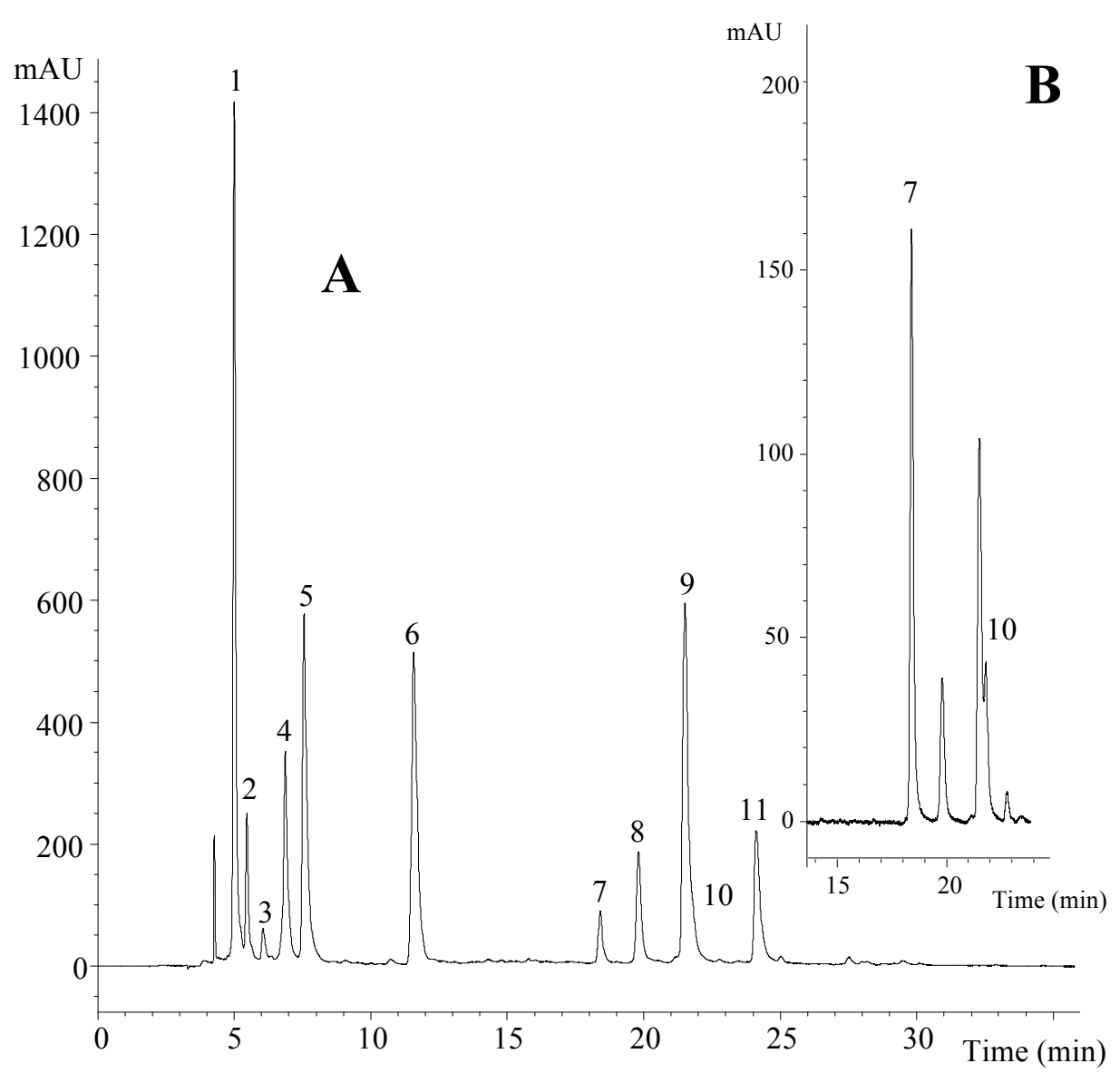

Figure 1. HPLC phenolic profile of methanol: water extracts prepared from Ilex paraguariensis leaves, obtained at $330 \mathrm{~nm}(\mathbf{A})$ and $370 \mathrm{~nm}(\mathbf{B})$. The peaks were identified in Table 4. 